\title{
HMGB1, neuronal excitability and epilepsy
}

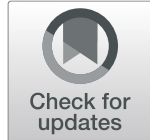

\author{
Sijie Dai ${ }^{1}$, Yang Zheng ${ }^{2}$, Yi Wang ${ }^{1,2}$ and Zhong Chen ${ }^{1,2^{*}}$ (D)
}

\begin{abstract}
Epilepsy is a common neurological disease caused by synchronous firing of hyperexcitable neurons. Currently, antiepileptic drugs remain the main choice to control seizure, but 30\% of patients are resistant to the drugs, which calls for more research on new promising targets. Neuroinflammation is closely associated with the development of epilepsy. As an important inflammatory factor, high mobility group protein B1 (HMGB1) has shown elevated expression and an increased proportion of translocation from the nucleus to the cytoplasm in patients with epilepsy and in multiple animal models of epilepsy. HMGB1 can act on downstream receptors such as Toll-like receptor 4 and receptor for advanced glycation end products, thereby activating interleukin (IL)-1 $\beta$ and nuclear factor kappa-B (NF-kB), which in turn act with glutamate receptors such as the N-methyl-D-aspartate (NMDA) receptors to aggravate hyperexcitability and epilepsy. The hyperexcitability can in turn stimulate the expression and translocation of HMGB1. Blocking HMGB1 and its downstream signaling pathways may be a direction for antiepileptic drug therapy. Here, we review the changes of HMGB1-related pathway in epileptic brains and its role in the modulation of neuronal excitability and epileptic seizure. Furthermore, we discuss the potentials of HMGB1 as a therapeutic target for epilepsy and provide perspective on future research on the role of HMGB1 signaling in epilepsy.
\end{abstract}

Keywords: HMGB1, Neuronal excitability, Epilepsy

\section{Background}

Epilepsy is a common neurological disease that affects about 60 million people worldwide, characterized by recurrent epileptic seizures [1]. Based on the typical concept that seizures are caused by synchronized firing of overexcited neurons, current antiepileptic drugs are used to control seizures by blocking the excitatory mechanisms or enhancing the inhibitory mechanisms. However, $30 \%$ of patients are still drug-resistant [2]. Repeated and unpredictable seizures not only affect the patient's brain function, leading to mental disorders and cognitive impairment, but may also be life-threatening [3-6]. Previous studies have found that inflammatory factors can directly or indirectly affect the electrical activities of neurons, thereby regulating the excitability of

\footnotetext{
* Correspondence: chenzhong@zju.edu.cn

'Institute of Pharmacology \& Toxicology, College of Pharmaceutical Sciences,

Zhejiang University, Hangzhou 310058, China

${ }^{2}$ Key Laboratory of Neuropharmacology and Translational Medicine of

Zhejiang Province, School of Pharmaceutical Sciences, Zhejiang Chinese

Medical University, Hangzhou 310053, China
}

the central nervous system (CNS) [7, 8]. Seizures can also cause inflammatory responses in the CNS, further resulting in damage of the CNS, which may be one of the pathological bases of refractory epilepsy [9]. Thus, neuroinflammation is closely related to the development of epilepsy. Understanding the underlying mechanisms of neuroinflammation in epilepsy would shed light on new targets for the treatment of refractory epilepsy.

High mobility group (HMG) protein is a structural protein in the eukaryotic nucleus that modifies, bends and alters the structure of DNA [10, 11]. The HMG superfamily mainly includes three families: HMGA, HMGB and HMGN [12]. The HMGB family includes three proteins HMGB1, HMGB2 and HMGB3 (previously HMG4 or HMG2B). Previous studies have shown that the pro-inflammatory cytokine HMGB1 is present in two different forms: intracellular HMGB1 which is mainly involved in gene transcription and regulation, and extracellular HMGB1 which functions as an inflammatory factor and participates in promoting tumor metastasis and inflammatory response [13, 14]. HMGB1

(c) The Author(s). 2021 Open Access This article is licensed under a Creative Commons Attribution 4.0 International License, which permits use, sharing, adaptation, distribution and reproduction in any medium or format, as long as you give appropriate credit to the original author(s) and the source, provide a link to the Creative Commons licence, and indicate if changes were made. The images or other third party material in this article are included in the article's Creative Commons licence, unless indicated otherwise in a credit line to the material. If material is not included in the article's Creative Commons licence and your intended use is not permitted by statutory regulation or exceeds the permitted use, you will need to obtain permission directly from the copyright holder. To view a copy of this licence, visit http://creativecommons.org/licenses/by/4.0/. 
can bind to a variety of receptors, such as receptors for advanced glycation end products (RAGE), toll-like receptor 2 (TLR2) and toll-like receptor 4 (TLR4) [15]. Upon binding to TLR2, TLR4 or RAGE, HMGB1 can promote the activation of cytokines, thereby affecting the downstream inflammatory factors that play an important role in the modulation of neural excitability and promote the development of epilepsy [16]. In this paper, we review changes in HMGB1-related pathways in the epileptic brain and their modulatory role in neuronal excitability and seizures, and summarize the potentials of HMGB1 to serve as a therapeutic target for epilepsy.

\section{HMGB1 in epilepsy patients}

Activation of the HMGB1-related pathway is evident in surgically resected brain tissues from epilepsy patients (Table 1). Zurolo et al. reported, for the first time, the increased expression of HMGB1 and its downstream receptors such as TLR2, TLR4 and RAGE in pathological brain tissues of patients with focal cortical dysplasia (FCD). They showed that IL-1 $\beta$ induced by HMGB1 nuclear transfer in glial cells mediated downstream inflammatory signaling pathways [17]. Zhang et al. have also found significantly increased proteins levels of TLR4, cytoplasm HMGB1 and inflammation factors such as IL$1 \beta$ and tumor necrosis factor- $\alpha$ (TNF- $\alpha$ ) in pathological tissues of FCD type II, compared to those in peri-FCD controls, together with an increased translocation of HMGB1 from nucleus to cytoplasm [18]. Furthermore, autoimmune epilepsy also involves the HMGB1-related immune activation. In patients with suspected autoimmune epilepsy, the cerebrospinal fluid (CSF) HMGB1 is upregulated significantly [19]. In patients with antiNMDAR encephalitis, the level of CSF HMGB1 is elevated, reflecting the underlying neuroinflammatory process [20]. These results suggest that the HMGB1TLR4 signaling pathway is intrinsically activated in epilepsy patients and may contribute to the hypereclampsia in developmental lesions and autoimmune-related epilepsy.

Apart from an increased level in the brain, elevated serum levels of HMGB1 have also been observed in epilepsy patients. After the onset of epilepsy, the total serum concentration of HMGB1 increases significantly and is especially high in patients with drug-resistant epilepsy [21], which may be one of the reasons for their susceptibility to recurrent seizures. The study of Kan et al. has also reported an increased serum HMGB1concentration in epilepsy patients and its correlation with seizure severity [22], which suggests that the serum levels of HMGB1 may be predictive of seizure severity and drug resistance in epilepsy.

Furthermore, application of anti-HMGB1 monoclonal antibody (mAb) onto the cortical slices from FCD patients and temporal lobe epilepsy patients lead to a significant decrease in amplitude and frequency of spontaneous discharges and an increase of action potential threshold of neuron [18], indicating the antiepileptic potential of anti-HMGB1 mAbs.

\section{HMGB1-related pathways in experimental epilepsy models}

HMGB1 and its related signaling pathways are also activated in animal models of epilepsy, as reflected by increased expression and increased exocytosis of HMGB1 (Table 2). In acute seizure models, HMGB1 upregulation and translocation have been commonly observed. Maroso et al. have found that the activated HMGB1 and its translocation from the nucleus to the cytoplasm are increased in mice with kainic acid (KA)-induced acute seizure [25]. Similarly, Shi et al. have found that the HMGB1-TLR4 signaling pathway is activated in mice after seizure attacks $[24,36]$. We have previously found that in diazepam (DZP)-refractory status epilepticus (SE) mice, the increased HMGB1 can rapidly reduce the onset threshold of acute SE, which is mediated by downstream receptor TLR4 [28]. The translocation of

Table 1 HMGB1-related findings in patients with epilepsy

\begin{tabular}{|c|c|c|}
\hline Type of epilepsy & Main findings & References \\
\hline FCD & $\begin{array}{l}\text { 个HMGB1 expression; } \\
\uparrow T L R 2, \text { TLR4, RAGE and IL-1 } \beta\end{array}$ & Zurolo et al. [17], 2011 \\
\hline FCD type $\|$ & $\begin{array}{l}\uparrow \text { expression and mRNA levels of cytoplasmic HMGB1, TLR4, IL-1 } \beta \text { and TNF-a; } \\
\uparrow \text { translocation of HMGB1 from nucleus to cytoplasm }\end{array}$ & Zhang et al. [18], 2018 \\
\hline Suspected autoimmune epilepsy & $\uparrow C S F$ HMGB1 & Han et al. [19], 2020. \\
\hline Anti-NMDAR encephalitis & $\uparrow C S F$ HMGB1 & Ai et al. [20], 2018 \\
\hline Drug-resistant epilepsy & $\uparrow$ Total serum concentration of HMGB1 & Lauren et al. [21], 2018 \\
\hline Drug-resistant epilepsy & 个Total serum concentration of HMGB1 and TLR4 expression & Kan et al. [22], 2019 \\
\hline Drug-resistant epilepsy & $\uparrow H M G B 1$ expression and translocation in patients' brain slices & Zhao et al. [23], 2017 \\
\hline
\end{tabular}

$\uparrow$ Increased, FCD Focal cortical dysplasia, HMGB1 High mobility group box protein 1, TLR2 Toll-like receptor 2, TLR4 Toll-like receptor 4, RAGE Receptors for advanced glycation end products, IL-1 $\beta$ Interleukin- $1 \beta$, TNF- $a$ Tumor necrosis factor- $a$, CSF Cerebrospinal fluid 
Table 2 HMGB1-related findings in experimental models of epilepsy

\begin{tabular}{|c|c|c|c|c|}
\hline Experimental model & $\begin{array}{l}\text { Animal strains or cell } \\
\text { lines }\end{array}$ & Model phases & Main findings & References \\
\hline CL-stimulated human microglial cell model & Human microglial cells & $\begin{array}{l}\text { After the } \\
\text { stimulation with } \\
\mathrm{CL}\end{array}$ & $\begin{array}{l}\uparrow H M G B 1, T L R 4, \text { RAGE, NF-KB p65 } \\
\text { and iNOS levels }\end{array}$ & $\begin{array}{l}\text { Shi et al. } \\
\text { [24], } 2018\end{array}$ \\
\hline KA-induced acute and chronic seizures in mice & $\begin{array}{l}\text { C57BL/6 mice and } \\
\mathrm{TLR}^{-/-} \mathrm{C} 3 \mathrm{H} / \mathrm{HeJ} \text { mice }\end{array}$ & $\begin{array}{l}\text { During acute and } \\
\text { chronic seizures }\end{array}$ & $\begin{array}{l}\uparrow H M G B 1 \text { and TLR4 levels; } \\
T L R 4^{-/-} \text {C } 3 \mathrm{H} / \text { HeJ mice are } \\
\text { resistant to KA-induced seizures }\end{array}$ & $\begin{array}{l}\text { Maroso } \\
\text { et al. [25], } \\
2010\end{array}$ \\
\hline $\begin{array}{l}\text { Sombati's cell model and kainic acid-induced epilepsy } \\
\text { model }\end{array}$ & SD rats & $\begin{array}{l}\text { After } 24 \mathrm{~h} \text { and } 72 \\
\mathrm{~h}\end{array}$ & $\begin{array}{l}\uparrow H M G B 1 \text { expression and } \\
\text { translocation }\end{array}$ & $\begin{array}{l}\text { Huang } \\
\text { et al. [26], } \\
2015\end{array}$ \\
\hline EAE model & $\begin{array}{l}\text { 8-to-10-week-old male } \\
\text { SD rats }\end{array}$ & During seizures & $\begin{array}{l}\text { 个HMGB1 expression; } \\
\text { } a c t i v a t i o n \text { of the TLR4/NF-kB } \\
\text { signaling pathway }\end{array}$ & $\begin{array}{l}\text { Liu et al. } \\
\text { [27], } 2017\end{array}$ \\
\hline $\begin{array}{l}\text { Acute seizure models (maximal electroshock seizure, } \\
\text { pentylenetetrazole-induced and kindling-induced), } \\
\text { and chronic epilepsy model (KA-induced) }\end{array}$ & 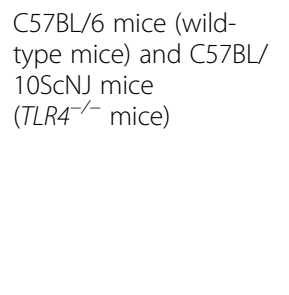 & During seizures & $\begin{array}{l}\text { Anti-HMGB1 mAb treated: } \\
\downarrow \text { seizure activities (dose- } \\
\text { dependently with minimal side } \\
\text { effects); } \\
\downarrow \text { HMGB1 translocation; } \\
\downarrow \text { seizure frequency; } \\
\uparrow \text { cognitive function; } \\
\text { The anti-seizure effect was absent } \\
\text { in } T L R 4^{-/-} \text {mice }\end{array}$ & $\begin{array}{l}\text { Zhao et al. } \\
\text { [23], } 2017\end{array}$ \\
\hline DZP-refractory SE & $\begin{array}{l}\text { Male wild-type mice } \\
(\mathrm{C} 57 \mathrm{BL} / 6 \mathrm{~J}) \text { and } T L R 4^{-/-} \\
\text {mice (C57BL/10ScNj) }\end{array}$ & $\begin{array}{l}\text { During refractory } \\
\text { SE period }\end{array}$ & $\begin{array}{l}\uparrow H M G B 1 \text { expression and } \\
\text { translocation; } \\
\text { Anti-HMGB1 mAb treated: } \\
\text { \incidence of SE and the severity } \\
\text { of seizure activity (TLR4- } \\
\text { dependent pathway); } \\
\text { Plasma HMGB1 level is closely } \\
\text { correlated with the therapeutic } \\
\text { response of anti-HMGB1 mAb }\end{array}$ & $\begin{array}{l}\text { Zhao et al. } \\
\text { [28], } 2020\end{array}$ \\
\hline Pilocarpine-induced SE & Female C57BL/6 N mice & $\begin{array}{l}\text { During status } \\
\text { epilepticus }\end{array}$ & $\begin{array}{l}\text { Anti-HMGB1 mAb treated: } \\
\downarrow \text { BBB breakdown; } \\
\downarrow \text { HMGB1 translocation; } \\
\downarrow \text { MCP-1, CXCL-1, TLR4, and IL-6 in } \\
\text { the hippocampus and cerebral } \\
\text { cortex } \\
\downarrow \text { apoptotic cells }\end{array}$ & $\begin{array}{l}\text { Fu et al. } \\
\text { [29], } 2017\end{array}$ \\
\hline KA-induced SE & P21 male Wistar rats & $\begin{array}{l}\text { During status } \\
\text { epilepticus }\end{array}$ & 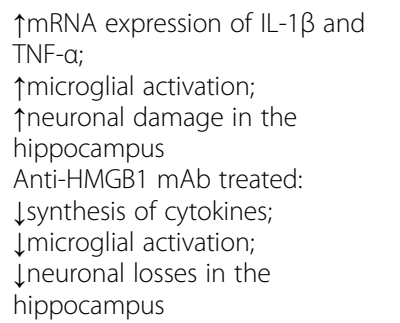 & $\begin{array}{l}\text { Li et al. } \\
\text { [30], } 2013\end{array}$ \\
\hline KA-induced neuronal death model & Male BALB/C mice & $\begin{array}{l}\mathrm{GL} 10 \mathrm{mg} / \mathrm{kg} \text {, i.p. } \\
30 \text { min before KA } \\
\text { administration }\end{array}$ & 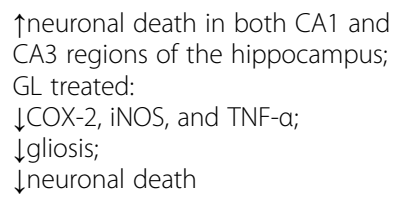 & $\begin{array}{l}\text { Luo et al. } \\
\text { [31], } 2013\end{array}$ \\
\hline KA-induced seizure model & Male BALB/c mice & $\begin{array}{l}\text { After } 3 h, 6 h, 12 \\
h, 4 d \text { and } 6 \text { days }\end{array}$ & $\begin{array}{l}\uparrow H M G B 1 \text { expression and } \\
\text { translocation; } \\
\uparrow H M G B 1 \text { serum concentration; } \\
\text { GL treated: } \\
\downarrow \text { HMGB1 expression and } \\
\text { translocation; } \\
\downarrow H M G B 1 \text { serum concentration }\end{array}$ & $\begin{array}{l}\text { Luo et al. } \\
\text { [32], } 2014\end{array}$ \\
\hline Lithium-pilocarpine-induced SE & Adult male SD rats & $\begin{array}{l}\text { During status } \\
\text { epilepticus }\end{array}$ & $\begin{array}{l}\uparrow H M G B 1 \text { expression and } \\
\text { translocation; }\end{array}$ & $\begin{array}{l}\text { Li et al. } \\
\text { [33], } 2019\end{array}$ \\
\hline
\end{tabular}


Table 2 HMGB1-related findings in experimental models of epilepsy (Continued)

\begin{tabular}{|c|c|c|c|c|}
\hline Experimental model & $\begin{array}{l}\text { Animal strains or cell } \\
\text { lines }\end{array}$ & Model phases & Main findings & References \\
\hline & & & $\begin{array}{l}\uparrow \text { HMGB1 serum concentration; } \\
\uparrow \text { neuronal damage; } \\
\uparrow B B B \text { disruption; } \\
\text { GL treated: } \\
\downarrow \text { HMGB1 expression and } \\
\text { translocation; } \\
\downarrow \text { HMGB1 serum concentration; } \\
\downarrow \text { neuronal damage; } \\
\downarrow \text { BBB disruption }\end{array}$ & \\
\hline KA-induced recurrent seizures model & P10 neonatal SD rats & $\begin{array}{l}\text { At early (14 PND) } \\
\text { and late ( } 30 \text { PND) } \\
\text { time points }\end{array}$ & $\begin{array}{l}\text { Celecoxib-treated: } \\
\uparrow \text { time latency of seizures; } \\
\downarrow \text { HMGB1 and TLR4 transcripts; } \\
\downarrow \text { COX-2 protein expression }\end{array}$ & $\begin{array}{l}\text { Morales- } \\
\text { Sosa et al. } \\
\text { [34], } 2018\end{array}$ \\
\hline Pilocarpine-induced SE & SD rats & After $24 \mathrm{~h}$ & 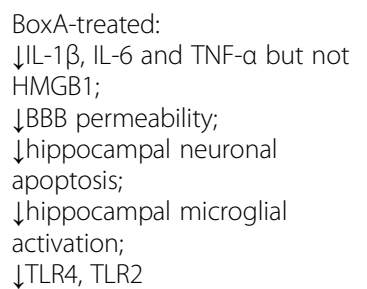 & $\begin{array}{l}\text { Yu et al. } \\
\text { [35], } 2019\end{array}$ \\
\hline
\end{tabular}

$\uparrow$ Increased, $\downarrow$ Decreased, CL Coriaria lactone, KA Kainic acid, DZP Diazepam, SE Status epilepticus, HMGB1 High mobility group box protein 1, mAb Monoclonal antibody, TLR4 Toll-like receptor 4, RAGE Receptors for advanced glycation end products, NF-KB Nuclear factor kappa-B, MCP-1 Monocyte chemotactic protein 1 , CXCL-1 CXC chemokine ligands 1, iNOS Inducible nitric-oxide synthase, IL-6 Interleukin-6, COX-2 Cyclooxygenase-2, TNF- $a$ Tumor necrosis factor-a, GL Glycyrrhizin, $B B B$ Blood-brain-barrier, PND Postnatal days, SD Sprague-Dawley, EAE experimental autoimmune encephalitis

HMGB1 from the nucleus to the cytoplasm in astrocytes and neurons is upregulated at the injury site in acute injury-induced epilepsy model [37].

The upregulation and translocation of HMGB1 have also been observed in chronic epilepsy models. In the above-mentioned study by Maroso et al., the same activation and translocation of HMGB1 were also observed in KA-induced chronic epilepsy mouse model. Huang et al. have also found upregulation of the expression and the translocation of HMGB1 in Sombati's cell model and in KA-induced epilepsy model [26]. In the rat model of experimental autoimmune encephalitis, elevated HMGB1 expression and activation of the TLR4/NF-kB signaling pathway also occur in the brain [27]. These results suggest that during the development of epilepsy, HMGB1 expression and translocation from the nucleus to the cytoplasm are upregulated. Therefore, it is speculated that HMGB1 plays an important role in both acute and chronic epileptogenesis [38].

In previous studies, HMGB1-related signaling pathways have been blocked to test the anti-epileptic effects of HMGB1 in different animal models [39] (Table 2). The most frequently used approach is the use of antiHMGB1 mAbs. We have found that injection of antiHMGB1 mAb into epileptic mice could effectively raise the epileptic seizure threshold, and reduce the duration of generalized seizures, as well as the frequency and severity of epileptic seizures. These inhibitory effects are observed in a dose-dependent manner in both acute seizure models (maximal electroshock seizures, pentylenetetrazol-induced and kindling-induced seizures) and chronic epilepsy models (KA-induced seizure) [23]. The anti-seizure effect of anti-HMGB1 mAb is mediated by downstream TLR4, as TLR4 ${ }^{-/-}$mice are resistant to seizure induction and the anti-seizure effect of anti-HMGB1 $\mathrm{mAb}$ is also vanished in $T L R 4^{-/-}$mice. Similar anti-seizure effect of anti-HMGB1 mAb has also been found in coriaria lactone-induced epilepsy model [24], pilocarpine-induced SE in mice $[28,29]$, and KAinduced SE in juvenile rats [30]. In DZP-refractory SE, anti-HMGB1 mAb can also reduce the incidence of SE, and prolong the DZP treatment time window from 30 min to $180 \mathrm{~min}$ [39]. These results suggest that antiHMGB1 mAb have potential anti-epileptic effects in varous epilepsy models.

Some other pharmacological agents have also been used to block the HMGB1-related signaling pathways (Table 2). In the acute KA-induced seizure model, glycyrrhizin suppression of HMGB1 in the hippocampus and serum induces attenuation of neuronal cell loss in mouse hippocampus [31,32]. Li et al. have found similar results in rats after lithium pilocarpine-induced SE [33]. In immature rats with KA-induced chronic epilepsy, celecoxib could exert neuroprotective effects through the HMGB1/TLR4 pathway [34]. Administration of nuclear factor kappa-B (NF- $k B$ ) inhibitors in rats with SE could reduce the mRNA expression of multi-drug resistance gene-1 and the level of p-gp through blocking the 
HMGB1/RAGE/NF-kB signaling pathway, thereby reducing the drug resistance rate of epilepsy [15]. In addition, in Sprague-Dawley rats with pilocarpine-induced SE, significant down-regulation of IL-1 $\beta$, IL- 6 and TNF- $\alpha$, but not of HMGB1, was found after treatment with BoxA (an anti-HMGB1 peptide), and these changes were associated with decreased maintenance of blood-brain barrier (BBB) integrity, reduced hippocampal neuronal apoptosis and reduced hippocampal microglial activation [35]. All these studies suggest that HMGB1-related pathway may be a potential target for antiepileptic drug therapy. Although previous studies have suggested that blocking HMGB1 signaling has promising anticonvulsant effects, the therapeutic effect remains to be validated in a more detailed manner, i.e., in different stages of epilepsy, as well as in different etiologies of epilepsy.

\section{HMGB1 relationship with neuronal excitability: mechanistic insights}

HMGB1 is usually located in the nucleus, and under various stressors (for example, cytokines, chemokines, heat, hypoxia, $\mathrm{H}_{2} \mathrm{O}_{2}$ and oncogenes), can transfer to the cytoplasm, including mitochondria and lysosome. One function of HMGB1 in the cytoplasm is to act as a positive regulator of autophagy [40]. HMGB1 can be actively secreted by immune cells or passively released by dead, dying or injured cells. Extracellular HMGB1 has a variety of activities and participates in multiple processes such as inflammation, immunity, cell migration, invasion, cell proliferation, cell differentiation, antibacterial defense, and tissue regeneration. However, under pathological conditions such as epilepsy, the expression and translocation of HMGB1 are significantly increased.

\section{HMGB1 promotes hyperexcitability}

The mechanisms underlying the role of HMGB1 (usually extracellular HMGB1) in epilepsy have been studied extensively, from perspectives of signaling pathways downstream of HMGB1 and the upregulation of HMGB1 induced by hyperexcitability. Harris et al. and Ravizza et al. have found that HMGB1 exerts a pro-epileptic effect through the TLR4/NF- $\mathrm{B}$ s signaling pathway [41, 42]. Iori et al. have further found that blocking the IL-1 receptor-1 (IL-1R1)/TLR4 pathway has a therapeutic effect in models of acquired epilepsy [43]. In addition, blocking the TLR4 signaling pathway could exert an anti-epileptic effect $[44,45]$. This effect has also been observed in brain specimens from patients with refractory epilepsy caused by FCD type II [46-48]. Yang further found that the HMGB1-TLR4 axis promotes the development of mesial temporal lobe epilepsy in pilocarpine-induced SE model of immature rats and in children [49]. In addition, activation of the IL-1R1/TLR4 axis in neurons can enhance $\mathrm{Ca}^{2+}$ influx via the NMDA receptors, which promotes the excitotoxicity and seizures $[46,50,51]$. IL- $1 \beta$ or HMGB1 may lower the seizure threshold by increasing neuronal sensitivity to NMDA, allowing more neurons to be recruited into the NMDA receptor-mediated excitatory loops [52].

In addition to the HMGB1-TLR4 signaling pathway, Iori et al. have found that HMGB1 activates RAGE, which contributes to the hyperexcitability and acute/ chronic epilepsies, as well as the pro-seizure effects of HMGB1 [50]. However, RAGE appears to have a less prominent contribution to seizures than TLR4, as a greater reduction in KA seizures has been found in $T L R 4^{-/-}$mice, whereas no delay in seizures found in $R A G E^{-/-}$mice.

\section{Hyperexcitability upregulates the HMGB1 signaling}

On the other hand, studies have revealed that hyperexcitability could upregulate HMGB1 expression and translocation. For example, activated astrocytes can release cytokines such as HMGB1 and IL-1 $\beta$ that induce transcriptional and post-transcriptional signaling in astrocytes themselves (autocrine actions) and in nearby cells (paracrine actions) [53]. De Simoni et al. have also found that under the hyperexcitability induced by SE in rats, HMGB1-related inflammatory cytokines such as IL$1 \beta$ are upregulated [54], which might then be correlated with the upregulation of HMGB1. Hyperexcitability can also activate microglia, inducing upregulation of inflammatory mediators such as HMGB1. The excitabilityinduced upregulation of HMGB1 is associated with seizure frequency and duration in patients with drugresistant epilepsy [55, 56]. In addition, the hyperexcitability induced by seizures can upregulate the expression of inflammatory factors including HMGB1 [57]. Therefore, the upregulation of HMGB1 expression and translocation is closely associated with hyperexcitability.

\section{Sources of HMGB1 signaling}

In addition, some studies have revealed possible cell types that contribute to the release of HMGB1. Devinsky et al. have found that the HMGB1 pathways mediated by the activation of astrocytes and microglia play an important role in the development of epilepsy [53]. HMGB1 is released from necrotic neurons via a NMDA receptor subunit $2 \mathrm{~B}$-mediated mechanism during traumatic brain injury. HMGB1 secretion occurs after severe injury and tissue hypoperfusion and is associated with post-traumatic coagulation abnormalities, activation of complement, and severe systemic inflammatory responses [58]. Other studies have found that macrophages also release HMGB1 [59, 60]. These studies suggest the presence of various sources of HMGB1: it is mainly released by neurons, glial cells such as astrocytes 
and microglia, and other immune cells such as macrophages.

Furthermore, immune cells such as macrophages and monocytes can actively secrete HMGB1 upon stimulation by cytokines such as interferon- $\gamma$, TNF and IL-1, or pathogen-derived molecules such as lipopolysaccharide [59, 61, 62]. Moreover, macrophages release HMGB1 upon activation by nucleotide-binding oligomerization domain (NOD) -like receptors-3 (NLRP3) or NLRC4 (nucleotide-binding oligomerization domains, leucinerich repeats and inflammasomes containing caspase recruitment domain-containing-4) $[59,60]$. The inflammasomes can mediate the release of cytoplasmic HMGB1 in activated immune cells. Further studies have shown that hyperexcitability could lead to the activation of the Janus kinase/signal transducer and activator of tran-ions (JAK/STAT1) pathway, which induces HMGB1 translocation from the nucleus to the cytoplasm and consequently cytoplasmic HMGB1 release [63]. Frank et al. further found that the redox state is a key molecular feature of HMGB1, as the reduced form of HMGB1 is chemotactic, whereas the disulfide form of HMGB1 (dsHMGB1) is pro-inflammatory. The NLRP3 inflammasome may play a role in the priming effects of dsHMGB1 [64]. These results indicate that the upregulation of HMGB1 is mainly induced by cytokines, pathogen-derived molecules and inflammasomes, and ds-HMGB1 plays an important role in hyperexcitability.

In particular, some studies have investigated signaling pathways associated with extracellular HMGB1. The extracellular HMGB1 forms complexes with other inflammatory molecules and is endocytosed into the endolysosomal system via RAGE. The internalized HMGB1 causes destabilization of lysosomal membranes and the leaky lysosomes allow HMGB1 partner molecules to enter cytoplasm that promote the transcription or regulation of inflammatory factors. Blockade of extracellular HMGB1 has the unique potential to improve clinical outcomes of various sterile and infectious inflammation. This therapeutic potential has already been proved in experimental sepsis models, in which the extracellular HMGB1 can successfully target TLR4 and RAGE even at later time points [65]. However, how intracellular HMGB1 is related to epileptic seizure is still unclear. In addition, studies have shown that the destruction of $\mathrm{BBB}$ may be an important mediator in the detrimental effect of HMGB1 on epileptogenesis. HMGB1 can lead to BBB damage in the pilocarpine-induced SE model [29, 33, 35 , which further leads to aggravation of epilepsy in SE model [23, 66-68]. Therefore, blocking the expression and release of HMGB1 may be a potential therapeutic choice for epilepsy treatment. However, it remains elusive how HMGB1 causes BBB damage. It has been proposed that changes in gene expression, cell signal transduction and cell phenotype of vascular endothelial cells and pericytes might account for the HMGB1induced BBB damage [66].

In conclusion, HMGB1 can act on downstream receptors such as TLR4 and RAGE, activating their downstream IL- $1 \beta$ and NF- $\kappa B$, which in turn act with NMDA receptors to aggravate hyperexcitability and epilepsy. Hyperexcitability can also stimulate the expression and translocation of HMGB1 mainly in neurons, glial cells and immune cells. These effects may promote each other in a closed-loop manner. Extracellular HMGB1 may participate in the destruction of BBB. Blocking extracellular HMGB1 and its downstream signaling pathways, or inhibiting the hyperexcitability of glial cells may be a potential therapeutic target for antiepileptic drug development.

\section{Outlook}

Traditional epilepsy treatment strategies primarily target ion channels to reduce the excitability of neurons, thereby inhibiting the generation and development of epilepsy. However, long-term use of these drugs may affect the normal physiological functions of patients [69]. As an important inflammatory factor, HMGB1 bind to downstream receptors, such as TLR4 and RAGE, which in turn mediates neuroinflammatory responses through signaling pathways such as NMDA receptors. In this context, neurons can become over-excited and the brain network reshaped, lowering the threshold for seizure attack. In addition, the expression of HMGB1 and TLR4 in patient serum correlates with an increased risk and severity of seizures, and is associated with resistance to anti-epileptic drugs. There are still many questions waiting to be resolved (Fig. 1).

(1) It remains not fully clear concerning the specific cellular origin of HMGB1 after the onset of epilepsy and whether the answer varies across epileptic stages. If the specific cellular origin of HMGB1 in specific epileptic stages can be elucidated, and the role of HMGB1 in signaling pathways related with different seizures can be fully revealed with consideration of confounding factors, precise treatment may not be far from us.

(2) Given the strong association between HMGB1 activation and seizures, it remains unclear whether the serum level of HMGB1 can be harnessed as a biomarker of epilepsy for its severity, prognosis or therapeutic response. In addition, the sensitivity of serum HMGB1 concentration in predicting seizure severity in different epilepsy types needs to be further investigated. The translocation ratio of HMGB1 may be referred to as a potential predictor of epilepsy susceptibility.

(3) The specific involvement of HMGB1 in epileptogenesis is only partially resolved. The key molecules in the HMGB1-related pathway, and at a more macro level, 


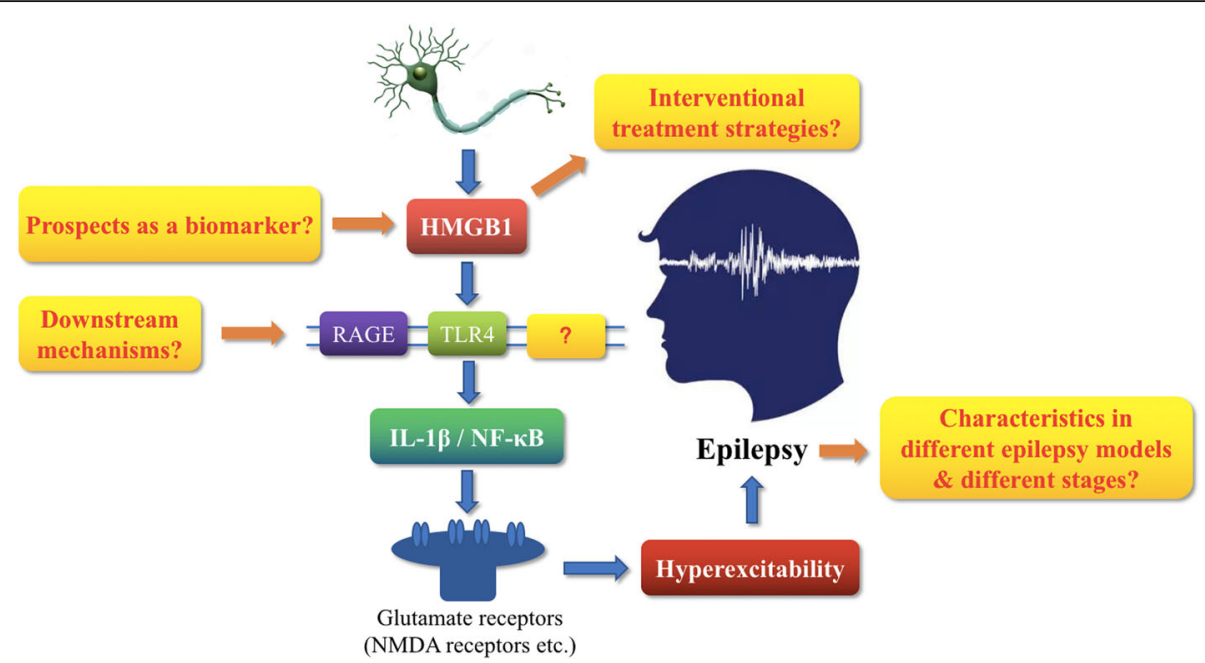

Fig. 1 Perspectives on the role of HMGB1 in epilepsy. HMGB1 exerts its epilepsy-promoting effects mainly by acting on receptors such as TLR4 and RAGE, activating their downstream IL-1 $\beta$ and NF-KB, which in turn act with glutamate receptors such as NMDA receptors to promote hyperexcitablilty and epilepsy. However, many questions remain to be resolved as listed in the schematic

whether HMGB1 upregulation underlies switch-on of certain brain circuits or activation of several brain regions, are important questions to be addressed.

(4) Previous studies have suggested that anti-HMGB1 $\mathrm{mAb}$ has anticonvulsant effects. The therapeutic effect remains to be validated in a more individualized manner, i.e. at different stages of epilepsy, and for epilepsy of different etiologies. Clinical trials are also needed to further confirm the anticonvulsant or antiepileptogenic effect of HMGB1 inhibition. In addition, whether selective inhibition of neuroglia such as astrocytes or microglia to downregulate the HMGB1 level can provide a more targeted anti-seizure effect needs further investigation.

\section{Conclusions}

In this review, we summarize the changes of HMGB1related pathway in epileptic brain and their role in the regulation of neuronal excitability and epileptic seizure. Further, we provide some perspectives for future studies that help reveal the exact roles of the HMGB1 signaling in epilepsy. Notably, a detailed understanding of HMGB1 at the microscale and macroscale level is needed. It remains a pivotal task to resolve the previous knowledge gap at different levels, from the signaling pathway to brain circuits and to epilepsy expression [60]. The use of modern neuroscience tools, including high-resolution recordings and genetically targeted manipulations might help to address those issues.

\section{Abbreviations}

BBB: Blood-brain barrier; CNS: Central nervous system; CSF: Cerebrospinal fluid; ds-HMGB1: Disulfide form HMGB1; DZP: Diazepam; FCD: Focal cortical

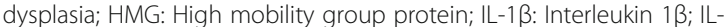
1R1: Interleukin-1 receptor-1; IL-6: Interleukin-6; JAK/STAT1: Janus kinase/ signal transducer and activator of tranions; KA: Kainic acid; mAb: Monoclonal antibodies; NF-kB: Nuclear factor kappa-B; NLRP3: Nucleotide binding oligomerization domain-like receptors-3; NMDA: N-methyl-D-aspartic acid; NOD: Nucleotide binding oligomerization domain; RAGE: Receptors for advanced glycation end products; SE: Status epilepticus; TLR2: Toll-like receptor 2; TLR4: Toll-like receptor 4; TNF-a: Tumor necrosis factor-a

\section{Acknowledgments}

Not applicable.

\section{Authors' contributions}

ZC conceptualized the review, and revised the manuscript. SJD and YZ conducted the systematic search and extracted the eligible studies. SJD drafted the study. YW and YZ revised the manuscript. All authors read and approved the final manuscript.

\section{Funding}

This project was supported by grants from the National Natural Science Foundation of China (81630098, and 81973298).

Availability of data and materials

Not applicable.

\section{Declarations}

Ethics approval and consent to participate Not applicable.

Consent for publication

All authors gave consent to publication of this review.

\section{Competing interests}

The authors declare no conflicts of interest.

Received: 18 May 2021 Accepted: 16 June 2021

Published online: 30 June 2021

\section{References}

1. Fisher RS, Acevedo C, Arzimanoglou A, Bogacz A, Cross JH, Elger CE, et al. ILAE official report: a practical clinical definition of epilepsy. Epilepsia. 2014; 55(4):475-82. https://doi.org/10.1111/epi.12550.

2. Chen T, Wang Y, He Z, Yu S, Shu H, Kuang Y. Progress in the study of the role of HMGB1 in the pathogenesis of epilepsy. Chin J Na. 2018;34(05):6436.

3. Pascente R, Frigerio F, Rizzi M, Porcu L, Boido M, Davids J, et al. Cognitive deficits and brain myo-inositol are early biomarkers of epileptogenesis in a 
rat model of epilepsy. Neurobiol Dis. 2016;93:146-55. https://doi.org/10.10 6/j.nbd.2016.05.001.

4. Liu AH, Chu M, Wang YP. Up-regulation of Trem2 inhibits hippocampal neuronal apoptosis and alleviates oxidative stress in epilepsy via the PI3K Akt pathway in mice. Neurosci Bull. 2019;35(3):471-85. https://doi.org/10.1 007/s12264-018-0324-5.

5. Yu B, Yuan B, Dai JK, Cheng TL, Xia SN, He L, et al. Reversal of social recognition deficit in adult mice with $\mathrm{MECP} 2$ duplication via normalization of MeCP2 in the medial prefrontal cortex. Neurosci Bull. 2020;36(6):570-84 https://doi.org/10.1007/s12264-020-00467-w.

6. Fei F, Wang $X$, Wang $Y$, Chen Z. Dissecting the role of subiculum in epilepsy: research update and translational potential. Prog Neurobiol. 2021 201:102029. https://doi.org/10.1016/j.pneurobio.2021.102029.

7. Iori V, Frigerio F, Vezzani A. Modulation of neuronal excitability by immune mediators in epilepsy. Curr Opin Pharmacol. 2016;26:118-23. https://doi. org/10.1016/j.coph.2015.11.002.

8. Paudel YN, Shaikh MF, Shah S, Kumari Y, Othman I. Role of inflammation in epilepsy and neurobehavioral comorbidities: implication for therapy. Eur J Pharmacol. 2018;837:145-55. https://doi.org/10.1016/j.ejphar.2018.08.020.

9. Van Vliet EA, Aronica E, Vezzani A, Ravizza T. Review: Neuroinflammatory pathways as treatment targets and biomarker candidates in epilepsy: emerging evidence from preclinical and clinical studies. Neuropathol Appl Neurobiol. 2018;44(1):91-111. https://doi.org/10.1111/nan.12444.

10. Stros M. HMGB proteins: interactions with DNA and chromatin. Biochim Biophys Acta. 2010;1799(1-2):101-13. https://doi.org/10.1016/j.bbagrm.2009. 09.008.

11. Ulloa L, Messmer D. High-mobility group box 1 (HMGB1) protein: friend and foe. Cytokine Growth Factor Rev. 2006;17(3):189-201. https://doi.org/10.101 6/j.cytogfr.2006.01.003.

12. Bustin M. Revised nomenclature for high mobility group (HMG) chromosomal proteins. Trends Biochem Sci. 2001;26(3):152-3. https://doi. org/10.1016/S0968-0004(00)01777-1.

13. Naglova H, Bucova M. HMGB1 and its physiological and pathological roles. Bratisl Lek Listy. 2012;113(3):163-71. https://doi.org/10.4149/bll_2012_039.

14. Venereau E, De Leo F, Mezzapelle R, Careccia G, Musco G, Bianchi ME. HMGB1 as biomarker and drug target. Pharmacol Res. 2016;111:534-44. https://doi.org/10.1016/j.phrs.2016.06.031.

15. Xie Y, Yu N, Chen Y, Zhang K, Ma HY, Di Q. HMGB1 regulates P-glycoprotein expression in status epilepticus rat brains via the RAGE/NF-KB signaling pathway. Mol Med Rep. 2017;16(2):1691-700. https://doi.org/10.3892/mmr.2 017.6772 .

16. Paudel YN, Shaikh MF, Chakraborti A, Kumari Y, Aledo-Serrano Á, Aleksovska K, et al. HMGB1: a common biomarker and potential target for TBI, Neuroinflammation, epilepsy, and cognitive dysfunction. Front Neurosci. 2018;12:628. https://doi.org/10.3389/fnins.2018.00628.

17. Zurolo E, lyer A, Maroso M, Carbonell C, Anink JJ, Ravizza T, et al. Activation of toll-like receptor, RAGE and HMGB1 signalling in malformations of cortical development. Brain. 2011;134(Pt 4):1015-32. https://doi.org/10.1093/ brain/awr032.

18. Zhang Z, Liu Q, Liu M, Wang H, Dong Y, Ji T, et al. Upregulation of HMGB1TLR4 inflammatory pathway in focal cortical dysplasia type II. J Neuroinflammation. 2018;15(1):27. https://doi.org/10.1186/s12974-018-10788.

19. Han Y, Yang L, Liu X, Feng Y, Pang Z, Lin Y. HMGB1/CXCL12-mediated immunity and Th17 cells might underlie highly suspected autoimmune epilepsy in elderly individuals. Neuropsychiatr Dis Treat. 2020;16:1285-93. https://doi.org/10.2147/NDT.S242766.

20. Ai P, Zhang X, Xie Z, Liu G, Liu X, Pan S, et al. The HMGB1 is increased in CSF of patients with an anti-NMDAR encephalitis. Acta Neurol Scand. 2018; 137(2):277-82. https://doi.org/10.1111/ane.12850.

21. Lauren W, Karen T, Emanuele R, Thimmasettappa T, Graeme J, Steve H, et al. High mobility group box 1 in the inflammatory pathogenesis of epilepsy: profiling circulating levels after experimental and clinical seizures. Lancet. 2014;383(Suppl 1):S105

22. Kan M, Song L, Zhang X, Zhang J, Fang P. Circulating high mobility group box-1 and toll-like receptor 4 expressions increase the risk and severity of epilepsy. Braz J Med Biol Res. 2019;52(7):e7374. https://doi.org/10.1 590/1414-431×20197374.

23. Zhao J, Wang Y, Xu C, Liu K, Wang Y, Chen L, et al. Therapeutic potential of an anti-high mobility group box-1 monoclonal antibody in epilepsy. Brain Behav Immun. 2017;64:308-19. https://doi.org/10.1016/j.bbi.2017.02.002.
24. Shi $Y$, Zhang L, Teng J, Miao W. HMGB1 mediates microglia activation via the TLR4/NF-kB pathway in coriaria lactone induced epilepsy. Mol Med Rep. 2018;17(4):5125-31. https://doi.org/10.3892/mmr.2018.8485.

25. Maroso M, Balosso S, Ravizza T, Liu J, Aronica E, lyer AM, et al. Toll-like receptor 4 and high-mobility group box-1 are involved in ictogenesis and can be targeted to reduce seizures. Nat Med. 2010;16(4):413-9. https://doi. org/10.1038/nm.2127.

26. Huang JS, Wu Y, Huang Q, Li SJ, Ye JM, Wei X, et al. Expression level and distribution of HMGB1 in Sombati's cell model and kainic acid-induced epilepsy model. Eur Rev Med Pharmacol Sci. 2015;19(15):2928-33.

27. Liu AH, Wu YT, Wang YP. MicroRNA-129-5p inhibits the development of autoimmune encephalomyelitis-related epilepsy by targeting HMGB1 through the TLR4/NF-kB signaling pathway. Brain Res Bull. 2017;132:139-49. https://doi.org/10.1016/j.brainresbull.2017.05.004.

28. Zhao J, Zheng Y, Liu K, Chen J, Lai N, Fei F, et al. HMGB1 is a therapeutic target and biomarker in diazepam-refractory status epilepticus with wide time window. Neurotherapeutics. 2020 Apr;17(2):710-21. https://doi.org/10.1 007/s13311-019-00815-3

29. Fu L, Liu K, Wake H, Teshigawara K, Yoshino T, Takahashi H, et al. Therapeutic effects of anti-HMGB1 monoclonal antibody on pilocarpineinduced status epilepticus in mice. Sci Rep. 2017;7(1):1179. https://doi.org/1 0.1038/s41598-017-01325-y.

30. Li Z, Li B, Zhu X, Yin P, Liu J, Huang S, et al. Neuroprotective effects of antihigh-mobility group box 1 antibody in juvenile rat hippocampus after kainic acid-induced status epilepticus. Neuroreport. 2013;24(14):785-90. https://doi. org/10.1097/WNR.0b013e328363fed3.

31. Luo L, Jin Y, Kim ID, Lee JK. Glycyrrhizin attenuates kainic acid-induced neuronal cell death in the mouse hippocampus. Exp Neurobiol. 2013;22(2): 107-15. https://doi.org/10.5607/en.2013.22.2.107.

32. Luo L, Jin Y, Kim ID, Lee JK. Glycyrrhizin suppresses HMGB1 inductions in the hippocampus and subsequent accumulation in serum of a kainic acidinduced seizure mouse model. Cell Mol Neurobiol. 2014;34(7):987-97. https://doi.org/10.1007/s10571-014-0075-4.

33. Li YJ, Wang L, Zhang B, Gao F, Yang CM. Glycyrrhizin, an HMGB1 inhibitor, exhibits neuroprotective effects in rats after lithium-pilocarpine-induced status epilepticus. J Pharm Pharmacol. 2019;71(3):390-9. https://doi.org/1 $0.1111 /$ jphp.13040.

34. Morales-Sosa M, Orozco-Suárez S, Vega-García A, Caballero-Chacón S, FeriaRomero IA. Immunomodulatory effect of celecoxib on HMGB1/TLR4 pathway in a recurrent seizures model in immature rats. Pharmacol Biochem Behav. 2018;170:79-86. https://doi.org/10.1016/j.pbb.2018.05.007.

35. Yu S, Zhang H, Hei Y, Yi X, Baskys A, Liu W, et al. High mobility group box-1 (HMGB1) antagonist BoxA suppresses status epilepticus-induced neuroinflammatory responses associated with toll-like receptor 2/4 downregulation in rats. Brain Res. 1717;2019:44-51.

36. Branco-Madeira F, Lambrecht BN. High mobility group box-1 recognition: the beginning of a RAGEless era? EMBO Mol Med. 2010;2(6):193-5. https:// doi.org/10.1002/emmm.201000077.

37. Peng A, He S, Zhu X, Qiu X, Zhang L, Lai W, et al. Advances in the study of inflammation in the pathogenesis of epilepsy. J Epilepsy. 2018;4(01):36-9.

38. Pauletti A, Terrone G, Shekh-Ahmad T, Salamone A, Ravizza T, Rizzi M, et al. Targeting oxidative stress improves disease outcomes in a rat model of acquired epilepsy. Brain. 2019;142(7):e39. https://doi.org/10.1093/brain/a wz130.

39. Musumeci D, Roviello GN, Montesarchio D. An overview on HMGB1 inhibitors as potential therapeutic agents in HMGB1-related pathologies. Pharmacol Ther. 2014;141(3):347-57. https://doi.org/10.1016/j.pharmthera.2013.11.001.

40. Tang D, Kang R, Livesey KM, Cheh CW, Farkas A, Loughran P, et al. Endogenous HMGB1 regulates autophagy. J Cell Biol. 2010;190(5):881-92. https://doi.org/10.1083/jcb.200911078.

41. Harris HE, Andersson U, Pisetsky DS. HMGB1: a multifunctional alarmin driving autoimmune and inflammatory disease. Nat Rev Rheumatol. 2012; 8(4):195-202. https://doi.org/10.1038/nrrheum.2011.222.

42. Ravizza T, Terrone G, Salamone A, Frigerio F, Balosso S, Antoine DJ, et al. High mobility group box 1 is a novel pathogenic factor and a mechanistic biomarker for epilepsy. Brain Behav Immun. 2018;72:14-21. https://doi.org/1 0.1016/j.bbi.2017.10.008,

43. Iori V, lyer AM, Ravizza T, Beltrame L, Paracchini L, Marchini S, et al. Blockade of the IL-1R1/TLR4 pathway mediates disease-modification therapeutic effects in a model of acquired epilepsy. Neurobiol Dis. 2017:99:12-23. https://doi.org/10.1016/j.nbd.2016.12.007. 
44. Kleen JK, Holmes GL. Taming TLR4 may ease seizures. Nat Med. 2010;16(4): 369-70. https://doi.org/10.1038/nm0410-369.

45. Maroso M, Balosso S, Ravizza T, Liu J, Bianchi ME, Vezzani A. Interleukin-1 type 1 receptor/toll-like receptor signalling in epilepsy: the importance of IL-1 beta and high-mobility group box 1. J Intern Med. 2011;270(4):319-26. https://doi.org/10.1111/j.1365-2796.2011.02431.x.

46. Yang $H$, Wang $H$, Andersson U. Targeting inflammation driven by HMGB1. Front Immunol. 2020;11:484. https://doi.org/10.3389/fimmu.2020.00484

47. Aronica E, Crino PB. Inflammation in epilepsy: clinical observations. Epilepsia. 2011:52(Suppl 3):26-32. https://doi.org/10.1111/j.1528-1167.2011.03033.x.

48. Blümcke I, Vinters HV, Armstrong D, Aronica E, Thom M, Spreafico R. Malformations of cortical development and epilepsies: neuropathological findings with emphasis on focal cortical dysplasia. Epileptic Disord. 2009; 11(3):181-93. https://doi.org/10.1684/epd.2009.0261.

49. Yang W, Li J, Shang Y, Zhao L, Wang M, Shi J, et al. HMGB1-TLR4 Axis plays a regulatory role in the pathogenesis of mesial temporal lobe epilepsy in immature rat model and children via the p38MAPK signaling pathway. Neurochem Res. 2017;42(4):1179-90. https://doi.org/10.1007/s11064-016-21 53-0.

50. Iori V, Maroso M, Rizzi M, lyer AM, Vertemara R, Carli M, et al. Receptor for advanced glycation Endproducts is upregulated in temporal lobe epilepsy and contributes to experimental seizures. Neurobiol Dis. 2013;58:102-14. https://doi.org/10.1016/j.nbd.2013.03.006.

51. Balosso S, Liu J, Bianchi ME, Vezzani A. Disulfide-containing high mobility group box-1 promotes $\mathrm{N}$-methyl-D-aspartate receptor function and excitotoxicity by activating toll-like receptor 4-dependent signaling in hippocampal neurons. Antioxid Redox Signal. 2014;21(12):1726-40. https:// doi.org/10.1089/ars.2013.5349.

52. Chiavegato A, Zurolo E, Losi G, Aronica E, Carmignoto G. The inflammatory molecules IL-1 $\beta$ and HMGB1 can rapidly enhance focal seizure generation in a brain slice model of temporal lobe epilepsy. Front Cell Neurosci. 2014;8: 155.

53. Devinsky O, Vezzani A, Najjar S, De Lanerolle NC, Rogawski MA. Glia and epilepsy: excitability and inflammation. Trends Neurosci. 2013;36(3):174-84. https://doi.org/10.1016/j.tins.2012.11.008.

54. De Simoni MG, Perego C, Ravizza T, Moneta D, Conti M, Marchesi F, et al. Inflammatory cytokines and related genes are induced in the rat hippocampus by limbic status epilepticus. Eur J Neurosci. 2000;12(7):262333. https://doi.org/10.1046/j.1460-9568.2000.00140.x.

55. Boer K, Spliet WG, van Rijen PC, Redeker S, Troost D, Aronica E. Evidence of activated microglia in focal cortical dysplasia. J Neuroimmunol. 2006;173(12):188-95. https://doi.org/10.1016/j.jneuroim.2006.01.002.

56. Ravizza T, Boer K, Redeker S, Spliet WG, van Rijen PC, Troost D, et al. The IL1 beta system in epilepsy-associated malformations of cortical development. Neurobiol Dis. 2006;24(1):128-43. https://doi.org/10.1016/j.nbd.2006.06.003.

57. Ravizza T, Gagliardi B, Noé F, Boer K, Aronica E, Vezzani A. Innate and adaptive immunity during epileptogenesis and spontaneous seizures: evidence from experimental models and human temporal lobe epilepsy. Neurobiol Dis. 2008;29(1):142-60. https://doi.org/10.1016/j.nbd.2007.08.012

58. Richard S, Min W, Su Z, Xu H. High mobility group box 1 and traumatic brain injury. J Behav Brain Sci. 2017;7(02):50-61. https://doi.org/10.4236/ jbbs.2017.72006.

59. Willingham SB, Allen IC, Bergstralh DT, Brickey WJ, Huang MT, Taxman DJ, et al. NLRP3 (NALP3, Cryopyrin) facilitates in vivo caspase-1 activation, necrosis, and HMGB1 release via inflammasome-dependent and -independent pathways. J Immunol. 2009;183(3):2008-15. https://doi.org/1 0.4049/jimmunol.0900138.

60. Lamkanfi M, Sarkar A, Vande Walle L, Vitari AC, Amer AO, Wewers MD, et al. Inflammasome-dependent release of the alarmin HMGB1 in endotoxemia. J Immunol. 2010;185(7):4385-92. https://doi.org/10.4049/jimmunol.1000803.

61. Wang $\mathrm{H}$, Bloom O, Zhang M, Vishnubhakat JM, Ombrellino M, Che J, et al. HMG-1 as a late mediator of endotoxin lethality in mice. Science. 1999: 285(5425):248-51. https://doi.org/10.1126/science.285.5425.248.

62. Rendon-Mitchell B, Ochani M, Li J, Han J, Wang H, Yang H, et al. IFN-gamma induces high mobility group box 1 protein release partly through a TNF. dependent mechanism. J Immunol. 2003;170(7):3890-7. https://doi.org/10.4 049/jimmunol.170.7.3890

63. Lu B, Antoine DJ, Kwan K, Lundbäck P, Wähämaa H, Schierbeck H, et al. JAK/STAT1 signaling promotes HMGB1 hyperacetylation and nuclear translocation. Proc Natl Acad Sci U S A. 2014:111(8):3068-73. https://doi. org/10.1073/pnas.1316925111.
64. Frank MG, Weber MD, Fonken LK, Hershman SA, Watkins LR, Maier SF. The redox state of the alarmin HMGB1 is a pivotal factor in neuroinflammatory and microglial priming: a role for the NLRP3 inflammasome. Brain Behav Immun. 2016:55:215-24. https://doi.org/10.1016/j.bbi.2015.10.009.

65. Andersson $U$, Yang $H$, Harris $H$. Extracellular HMGB1 as a therapeutic target in inflammatory diseases. Expert Opin Ther Targets. 2018;22(3):263-77. https://doi.org/10.1080/14728222.2018.1439924.

66. Nishibori M, Wang D, Ousaka D, Wake H. High mobility group Box-1 and blood-brain barrier disruption. Cells. 2020;9(12):2650. https://doi.org/10.3390/ cells9122650.

67. Zhang J, Takahashi HK, Liu K, Wake H, Liu R, Maruo T, et al. Anti-high mobility group box-1 monoclonal antibody protects the blood-brain barrier from ischemia-induced disruption in rats. Stroke. 2011:42(5):1420-8. https:// doi.org/10.1161/STROKEAHA.110.598334.

68. van Vliet EA, da Costa AS, Redeker S, van Schaik R, Aronica E, Gorter JA Blood-brain barrier leakage may lead to progression of temporal lobe epilepsy. Brain. 2007;130(Pt 2):521-34. https://doi.org/10.1093/brain/awl318.

69. Wykes RC, Heeroma JH, Mantoan L, Zheng K, MacDonald DC, Deisseroth K, et al. Optogenetic and potassium channel gene therapy in a rodent model of focal neocortical epilepsy. Sci Transl Med. 2012;4(161):161ra152.

\section{Ready to submit your research? Choose BMC and benefit from:}

- fast, convenient online submission

- thorough peer review by experienced researchers in your field

- rapid publication on acceptance

- support for research data, including large and complex data types

- gold Open Access which fosters wider collaboration and increased citations

- maximum visibility for your research: over $100 \mathrm{M}$ website views per year

At BMC, research is always in progress.

Learn more biomedcentral.com/submissions 